\title{
Changes in floristic richness and diversity of phytocoenoses on riparian habitats affected by diverse land-use forms
}

\author{
Adam Barcikowski*, Wiesław Cyzman, Marcin Marchwiński, Anna Wojciechowska \\ Nicolaus Copernicus University, Faculty of Biology and Environmental Protection, \\ Department of Plant Ecology and Nature Conservation, Lwowska 1, 87-100 Toruń, Poland, \\ *e-mail: barcik@umk.pl
}

\begin{abstract}
In many ecological studies the theory prevails that the increased human economic activity can lead to simplification of species composition of phytocoenoses and a decline of their species diversity. However, there are also other views on this issue. Therefore, an attempt was undertaken to verify these contradictory opinions. The research was conducted at three sites characterised by a diversified and intensified land use form (the nature reserve, 50 year-old poplar plantation and a grassland). The results from the nature reserve were compared with the data for 1963-1965 when other plant communities dominated in the reserve.

The results of field observations collected in the form of relevés were used to assess the number of species, $\alpha$-species diversity of phytocoenoses and ß-diversity.

The largest number of species was found in the meadow, a fewer species were recorded in the reserve and the fewest in the poplar plantation; whereas the average number of species per relevé and the differences between the sites were minor. The species heterogeneity index varied within the range of 3.11-3.36, whereas the extreme differences were recorded in the reserve between the current results and the results from the 1960s. The studied phytocoenoses differed mostly in ß-diversity. The average index for the poplar plantation was lower than mean values of indices recorded in communities of the riparian forest and meadows.

The obtained results support the opinion about non linear correlation between the increased disturbances and the decline of species richness and species diversity in phytocoenoses.
\end{abstract}

Key words: $\alpha$ - diversity, $\beta$-diversity, Shannon index, ecosystem functioning, conservation, stability.

\section{Introduction}

Despite the rich history of researches on the relationships between stability and diversity of ecosystems, despite the undertaken attempts at solving this issue already in the 1970s (van Dobben \& Lowe-McConnell 1975), the interest in the problem does not decline (Ives \& Carpenter 2007). As evidenced by several ecological papers, the economic activity based on natural ecosystems may lead to simplification of species composition of phytocoenoses and a decline of their species diversity. However, there are also different views on this issue (Sala 1995; Anderson 1995; Schwartz et al. 2000; Loreau et al. 2002; Grace et al. 2007).

In the view of this controversy, an attempt was undertaken to verify the contradictory opinions. For that pur- pose, the research was carried out in three biocenoses of riparian habitats, characterised by a diverse and intensified form of land use. Those were: the nature reserve „Wielka Kępa Ostromecka”, dominated by the association Ficario-Ulmetum minoris, ca. 50 year-old poplar plantation and the grassland dominated by the association Alopecuretum pratensis, used alternately as a grazing land or meadow. In addition, the results from the nature reserve were compared with the literature data for 1963-1965 when plant communities of Ficario-Ulmetum minoris and Salici-Populetum dominated in the reserve.

A question was put as to what way the increased pressure related to exploitation of riparian habitats affects the floristic richness and diversity of phytocoenoses? 


\section{The study area}

The studied area is situated in the valley of the Vistula River near the village of Ostromecko. Both the forest reserve „Wielka Kępa Ostromecka”, as well as the adjacent poplar plantation and the meadow covered the inundation terrace of the Vistula River with the altitude of 26 $\mathrm{m}$ a.s.l. stretching along the right river bank at a distance of $15-400 \mathrm{~m}$ from the main stream. The surface layer of the terrace is built of alluvial sandy and silty deposits on fluvioglacial sands reaching the stratified clay. The study area was almost flat and small relative altitude differences ranged from 1.5 to $2 \mathrm{~m}$ (Kępczyński \& Wilkoń-Michalska 1967).

The nature reserve „Wielka Kępa Ostromecka” had existed already before the Second World War. In 1940-1950 new boundaries were delimited -28.7 ha of the riparian forest were included in the strict protection programme. At present only one association Ficario-Ulmetum minoris can be identified (according to the phytosociological typology) in the nature reserve. Whereas in the 1960s, the presence of two associations Ficario-Ulmetum minoris and Salici-Populetum was confirmed (Kępczyński \& Wilkon-Michalska 1.c.). The uppermost tree layer in the phytocoenoses of the nature reserve is composed of the following species: Ulmus minor, Quercus robur, Fraxinus excelsior, and to a lesser extent: Acer platanoides. Also Populus alba is present in this layer, which is a remnant of the willow-poplar floodplain forest. Monumental specimens of Populus nigra are remarkable; they reach impressive height of up to $35 \mathrm{~m}$, breast height diameter of up to $130 \mathrm{~cm}$ and a perimeter of 250-year old specimens comes to $7 \mathrm{~m}$. A lower tree layer is composed of Ulmus minor, Fraxinus excelsior, as well as Quercus robur, Acer platanoides and Prunus padus. The following shrubs occur abundantly: Cornus sanguinea, Sambucus nigra and Prunus padus. Also Crataegus monogyna, Fraxinus excelsior and Ulmus minor are represented in large numbers. The herb layer is quite abundant all over the forest. Some of the species form dense, large patches or occur in large numbers, e.g. Aegopodium podagraria, Galium aparine, Glechoma hederacea, Lamium maculatum, Urtica dioica and Impatiens parviflora. Ranunculus ficaria is a dominant spring element.

The nature reserve bordering on the poplar plantation was established in the 1950s. The tree layer of the plantation is composed of a poplar cultivar defined as Populus canadensis. Apart from the poplar, the tree layer consists of Acer negundo, Ulmus minor and Alnus incana. The shrub layer consists of mainly Cornus sanguinea, Crataegus monogyna and Ulmus minor, as well as Acer negundo and Prunus padus. The herb layer of the plantation is relatively well developed. The dominant herbaceous species are as follows: Festuca gigantea, Galium aparine, Glecho- ma hederacea, Solidago gigantea, Urtica dioica and Impatiens parviflora.

The presence of the association Alopecuretum pratensis (identified according to the phytosociological typology) was recorded in the meadow adjacent to the poplar plantation and the nature reserve. Apart from the foxtail grass a species characteristic of this typological unit - also other species occurred abundantly, including Lychnis flos-cuculi, Plantago lanceolata, Vicia cracca, Poa pratensis, Lathyrus pratensis and many others typical of this phytocoenosis affected by human activity.

\section{Methods}

\subsection{Field studies}

A floristic inventory was carried out in the studied area and 45 relevés were made applying the Braun-Blanquet (1964) method (12 relevés in the meadow, 8 relevés in the poplar plantation and 25 relevés in the nature reserve „Wielka Kępa Ostromecka”). A standard surface area of relevés was applied: $100 \mathrm{~m}^{2}$ in the meadow and $400 \mathrm{~m}^{2}$ in the forest communities of the nature reserve and the poplar plantation. Apart from relevés made in the field, 22 relevés made in the reserve in 1963-1965 (Kępczyński \& Wilkoń-Michalska 1967) were included in this study.

Cover-abundance of individual species was estimated according to the seven-degree scale of Braun-Blanquet.

\subsection{Calculations and statistical analysis}

Species richness and species diversity were calculated in 67 relevés. The significance of differences between mean values of the number of species and diversity indices for the identified plant communities was assessed with the Kruskal-Wallis test using the statistical software PAST. Before performing the calculations and statistical analysis, cover-abundance values for each plant species were transformed from the Braun-Blanquet scale to the nine-degree scale (van der Maarel 1979).

Species diversity of phytocoenoses according to Whittaker was assessed based on $\alpha$-species diversity of phytocoenoses (heterogeneity) - point diversity and B-diversity pattern diversity. Point diversity was calculated according to Shannon's index (Shannon \& Weaver 1949), applying the natural logarithm:

$$
H=-\sum_{i=1}^{s} p_{i} \log p_{i}
$$

where:

$s$ - number of species in relvevé,

$p$ - probability that a randomly selected specimen represents species $i$ : 


$$
p_{i}=n_{i} / N
$$

where:

$n_{i-}$ coefficient of species importance (abundance),

$N$ - the total of importance coefficients (abundance) for all species.

Pattern diversity was calculated according to the formula proposed by Whittaker (1960, 1977):

$$
\beta W=S / L-1
$$

where:

$S$ - the number of species in a community was calculated according to the list of species in synoptic table,

$L-$ the average number of species per relevé.

\subsection{Syntaxonomic numerical analysis}

The collected material (67 relevés) was divided into syntaxonomic units applying the hierarchical (grouping) classification with the use of the software TWINSPAN. Statistical evaluation of the significance of the distinguished units was assessed by the Monte Carlo test (499 permutations). This test was also used to assess the significance of ordination axes. This assessment was performed together with the discriminant analysis CVA (Canonical Variates Analysis) using the software Canoco 4.0 (ter Braak \& Šmilauer 2002).

\section{Results}

As indicated in the description of the studied communities, the differences in the riparian habitats' use: the nature reserve conservation, the poplar plantation and the grassland, determined the diverse affinity of the studied communities to phytosociological units. Numerical analysis of 67 relevés confirmed these major syntaxonomic differences between the studied phytocoenoses. Both the classification and ordination analysis indicate major differences between the meadow phytocoenosis and the natural forest phytocoenoses, and the poplar plantation (Figs 1,2). Whereas, the species composition of the poplar plantation was similar to a certain extent to communities of Ficario-Ulmetum minoris and to riparian Salici populetum reported in the reserve in 1963-65. A certain difference between the riparian community and the remaining studied communities is due to higher contribution of Populus nigra in the tree layer A1 (Fig.1).

The community of Ficario-Ulmetum occurring in the reserve in the 1960s has a slightly different syntaxonomic position compared with the same community in 2001 . Only 13 relevés from the 1960 s was grouped in the classification analysis as a separate group (Fig. 1). The other relevés were classified together with the relevés from 2001 ( 2 relevés) or were included among relevés of the remaining communities ( 2 relevés). In the first case, the similarity between communities was defined by a high contribution of Galium aparine, Geum urbanum, Lamium maculatum, as well as seedlings of Acer platanoides. In the second case, the similarity between the relevés from the community Ficario-Ulmetum from both studied periods and relevés made in the poplar plantation was defined by exceptionally high contribution of Impatiens parviflora (more than 50\% of the vegetation cover in each relevé), while in the other relevés of this community the species is absent or occurs in scanty quantities. The group of relevés from 2001 was not distinguished as a species specific group by any of the performed analyses.

The results of observations performed in the field and found in the literature, the floristic inventory and relevés

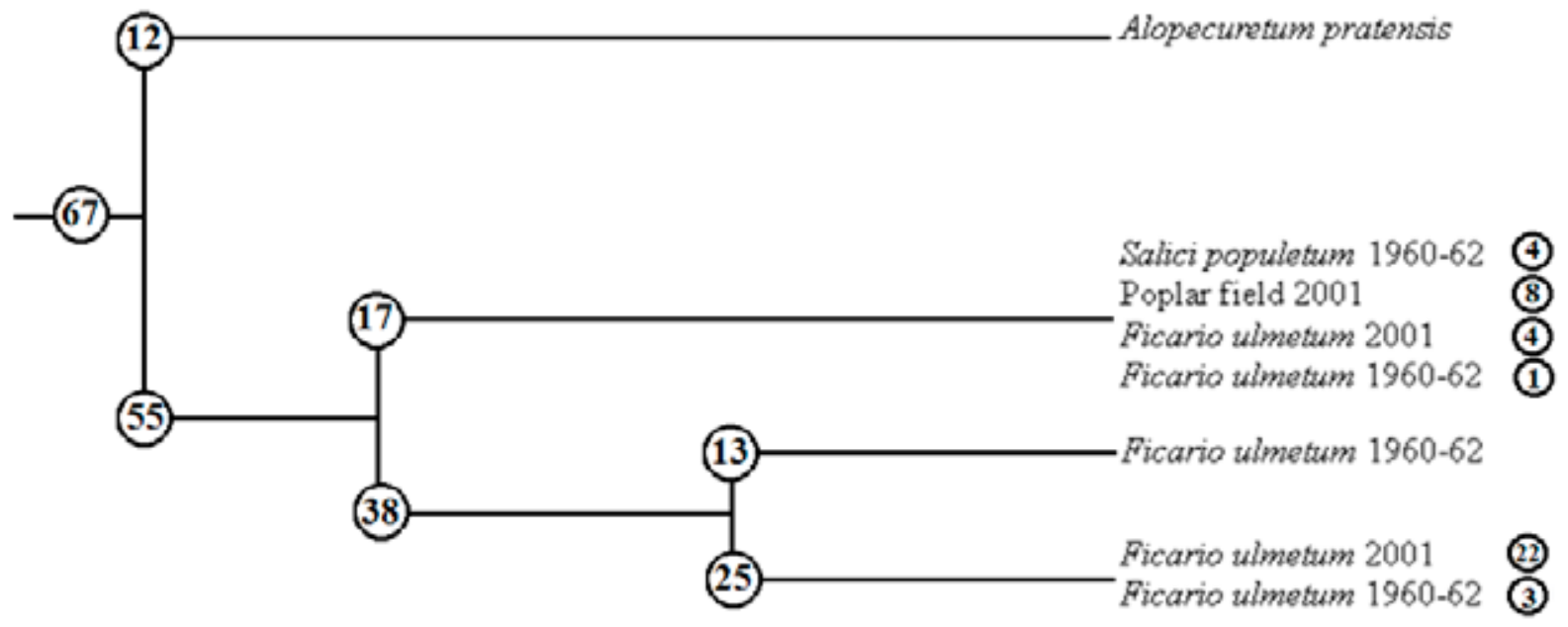

Figure 1. Hierarchical classification analysis. Numbers in circles indicate the number of relevés at each division level 


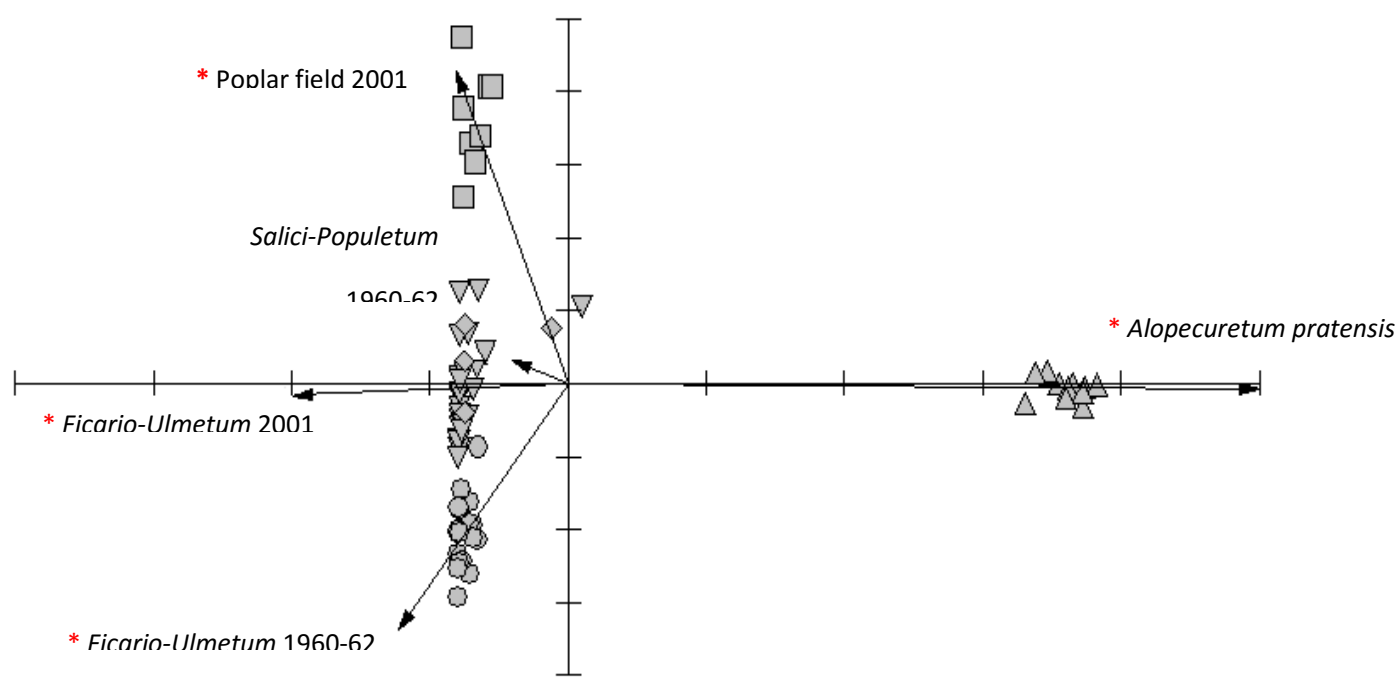

Figure 2. Canonical Variates Analysis of relevés from five plant communities. The asterisks stand for $\mathrm{p}<0.01$; all significant variables together explain $23 \%$ of the total variance. All canonical axes are statistically significant

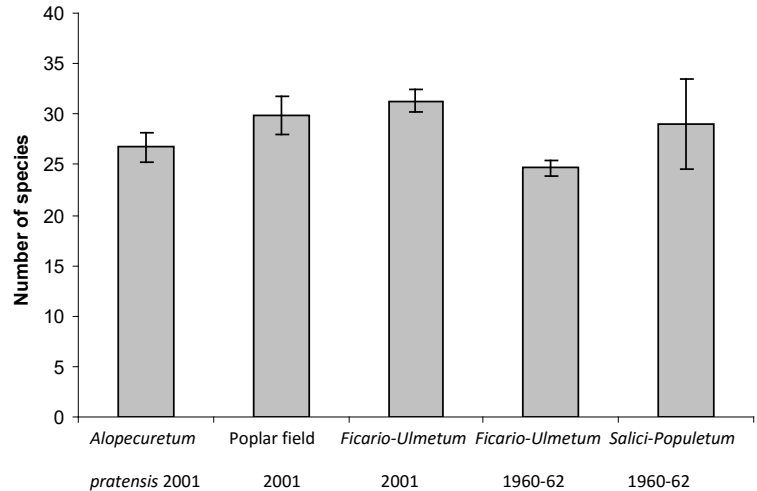

Figure 3. The average number of species per relevé $[ \pm \mathrm{SE}]$ in five plant communities. Differences between columns are significant $(\mathrm{p}<0.01)$ according to the Kruskal-Wallis test

allow to assess the number of species in the studied communities, as well as $\alpha$-species diversity (heterogeneity) of phytocoenoses and $\beta$-diversity.

The largest number of species in the studied communities was recorded in the meadow (87), a fewer species were found in the reserve, i.e. 82 species in the 1960s and 81 species at present. The smallest number of species was found in the poplar plantation (55 species; Fig. 5). In respect of the average number of species per relevé, which ranges from 20 to 27, the absolute differences between the sites were significant (Fig. 3). This difference was due to only a significantly smaller number of species reported in

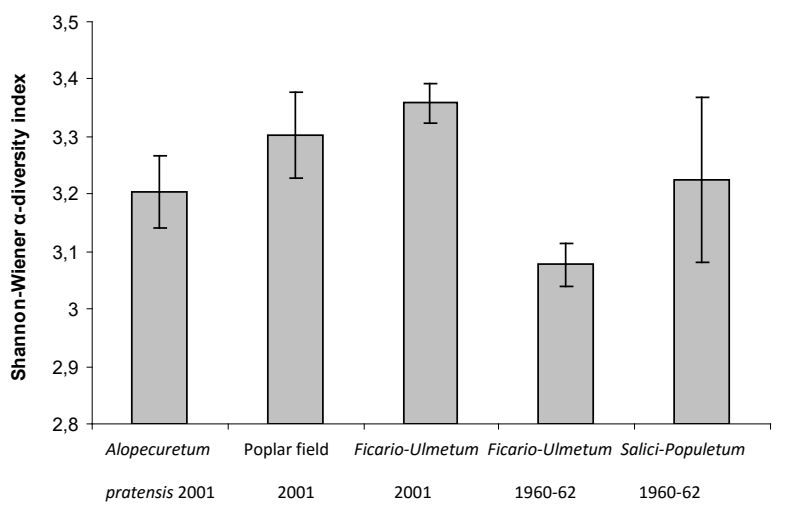

Figure 4. Shannon-Wiener $\alpha$-diversity index $[ \pm \mathrm{SE}]$ of five plant communities. Differences between columns are significant $(\mathrm{p}<0.001)$ as confirmed by the Kruskal-Wallis test

the community of Ficario-Ulmetum in the 1960s, as compared to other communities between which the significant differences were no longer observed.

The average species heterogeneity index varied for the studied communities within the range of 3.11-3.36, whereas the extreme differences were recorded in the reserve between the current results and those from the 1960s (Fig. 4). The highest diversity index $H=3.36$ was reported in the reserve, in the community of Ficario-Ulmetum in 2001. Slightly lower values of the Shannon index were obtained for the poplar plantation and for the meadow with the Alopecuretum pratensis association (3.31 and 3.21, respective- 


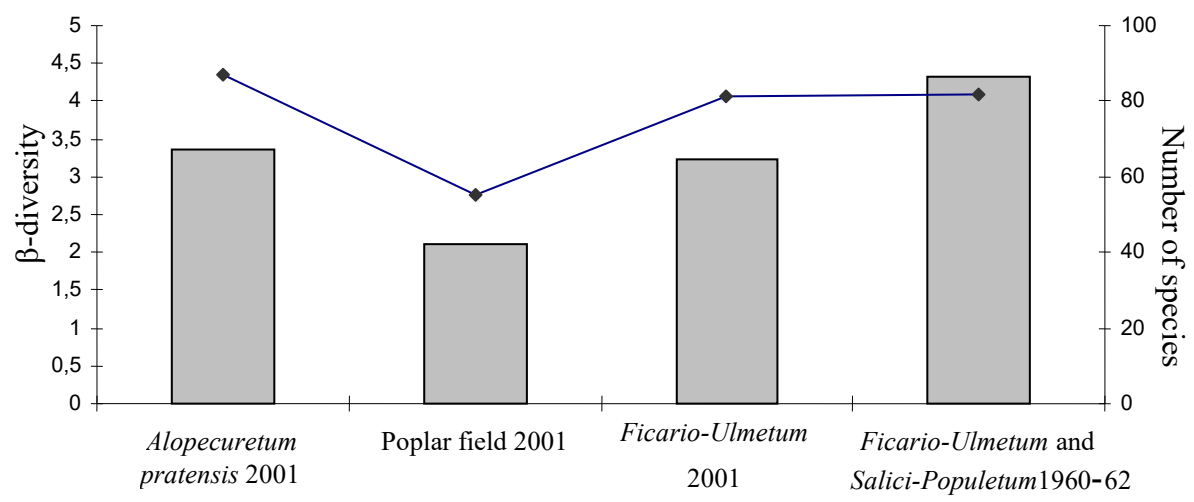

Figure 5. $\beta$-diversity index (left side) and the total number of species (right side) of the selected plant communities

ly); by far the smallest value of the diversity index (3.11) was obtained for the reserve in the 1960s.

The studied phytocoenoses differed mostly in the values of the $\beta$-diversity index. The lowest average index was determined for the poplar plantation, i.e. 2.11. The highest $\beta W$ value $=4.32$ was recorded in the natural communities of the nature reserve in 1963-1965. Slightly lower values, compared to mean values of indices reported 40 years earlier in the communities of the riparian forest, were recorded in the reserve in 2001, and in the meadow (3.24 and 3.35 , respectively).

\section{Discussion and conclusions}

It is difficult to obtain clear solutions (rules) based on relationships between diversity and stability, not only because it is a very complex and multifaceted problem. The main difficulties consist in ambiguous definitions of stability and diversity. It also seems that Ives and Carpenter (2007) were right about the fact that the type of disturbances affecting a given ecosystem is of major importance for the described relationships. To avoid the aforementioned difficulties in this study, the „diversity” was restricted to the assessment of the number of species, the Shannon index and the B-diversity index. For the clarity of discussion on the problem, an inaccurate notion of stability was omitted (Orians 1975; Ives \& Carpenter 1.c.), and the careful selection of the studied sites reduced the disturbances affecting the ecosystems to agrotechnical treatments of a different extent of intensity. And thus, the meadow phytocoenosis was exposed to the strongest anthropopressure. Clearing of primaeval forest in the distant past and annual treatments in the form of grazing or mowing contributed to that situation. The poplar cultivation was exposed to the pressure of much lesser extent and shorter duration. Approximately 50 years ago, the natural riparian forest was cut down and fast-growing trees were planted at this place. Whereas no direct human action was reported on natural habitats of the nature reserve. The observed changes in the structure of phytocoenoses and in the floristic composition resulted from natural processes of ecological succession.

The obtained results revealed that the increased human pressure, diverse in terms of quality and intensity, resulted in significant syntaxonomic differences between the sites. However, despite the phytosociological differences between the communities, no major differences were recorded between them in respect of the average number of species per relevé and the average species heterogeneity index. Furthermore, the numerical values of the $\alpha$-diversity index (3.11-3.36) were similar to the results obtained for natural oak-hornbeam forests from the Vistula valley (Barcikowski et al. 2005).

The obtained results support the view about a weak linear correlation between the increased disturbance, related to land-use treatments, and the decline of species richness and species diversity of phytocoenoses. Given a significant reduction in the value of $\beta$-diversity in the poplar plantation, one can agree with the conclusion that a significant factor affecting the reduction of phytocoenoses' diversity is not so much the intensification of disturbances as it is their type. It should also be pointed out that changes, both in the number of species and in the values of Shannon's index observed in natural riparian phytocoenoses of the nature reserve in the process of natural dynamics, were statistically significantly higher than changes induced by increased disturbances resulting from intensification of land-use treatments.

An increase in the intensity of pressure resulting from the use of riparian habitats: the nature reserve, the poplar plantation and the grassland, did not induce a simple relation between degradation of phytocoenoses and their complexity defined by the number of species, the Shannon index and ß-diversity index. 


\section{References}

Anderson J.M., 1995, The soil system [in:] H.A. Mooney, J. Lubchenco, R. Dirzo, O.E. Sala (eds), Global Biodiversity Assessment, Cambridge Univ. Press, Cambridge: $406-412$.

Barcikowski A., Nienartowicz A., Nowacka J., Rozpiórska M., Wielgosz M. \& Wojciechowska A., 2005, Studies on floristic diversity of forest phytocoenoses from the Las Piwnicki forest reserve near Toruń, Polish Botanical Studies 19: 203-209.

Braun-Blanquet J., 1964, Pflanzensoziologie, Grundzüge der Vegetationskunde, 3. Aufl., Springer Publ., Wien, New York.

Grace J. B., Anderson T. M., Smith M. D., Seabloom E., Andelman S. J., Meche G., Weiher E., Allain L. K., Jutila H., Sankaran M., Knops J., Ritchie M. \& Willig M. R., 2007, Does species diversity limit productivity in natural grassland communities?, Ecology Letters 10: 680-689. doi: 10.1111/j.1461-0248.2007.01058.x

Ives A.R. \& Carpenter S.R., 2007, Stability and diversity of ecosystems, Science 317:58-62. doi: 10.1126/science. 1133258

Kępczyński K. \& Wilkoń-Michalska J., 1967, Stosunki florystyczno-fitosocjologiczne rezerwatów „Wielka Kępa Ostromecka” i „Las Mariański” [Floristic and phytosociological description of the nature reserves „Wielka Kępa Ostromecka” and „Las Mariański”], Stud. Soc. Sc. Tor. VII(6), PWN, Poznań.

Loreau M., Downing A., Emmerson M., Gonzales A., Hughes J., Inchausti P., Joshi J., Norberg J. \& Sala O., 2002, A new look at the relationships between diversity and stability, [in:] M. Loreau, S. Naeem, P. Inchausti (eds), Biodiversity and Ecosystem Functioning: Synthesis and Perspectives, Oxford Univ. Press, Oxford: 79-91.
Orians G.H., 1975, Diversity, stability and maturity in natural ecosystems, [in:] W.H. van Dobben, R.H. Lowe-McConnell (eds), Unifying concepts in ecology, Junk, The Hague, Wageningen: 139-150. doi: 10.1007/978-94-010-1954-5 11

Sala O.E., 1995, Human-induced perturbations biodiversity, [in:] H.A. Mooney, J. Lubchenco, R. Dirzo, O.E. Sala (eds), Global Biodiversity Assessment, Cambridge Univ. Press, Cambridge: 318-325.

Schwartz M.W., Brigham C.A., Hoeksema J.D., Lyons K.G., Mills M.H. \& van Mantgem P.J., 2000, Linking biodiversity to ecosystem function: implications for conservation ecology, Oecologia 122: 297-305. doi: $10.1007 / \mathrm{s} 004420050035$

Shannon C.E. \& Weaver W., 1949, The mathematical theory of communication, Univ. Illinois Press, Urbana.

ter Braak C.J.F. \& Šmilauer P., 2002, CANOCO Reference Manual and CanoDraw for Windows User's Guide: Software for Canonical Community Ordination (version 4.5), Microcomputer Power, Ithaca, NY, USA.

van der Maarel E., 1979, Transformation of cover-abundance values in phytosociology and its effect on community similarity, Vegetatio 39: 97-114.

van Dobben W.H. \& Lowe-McConnell R.H., 1975, Unifying concepts in ecology, Junk, The Hague, Wageningen.

Whittaker R.H., 1960, Vegetation of the Siskiyou Mountains Oregon, and California, Ecol. Monogr. 30: 279338. doi: $10.2307 / 1943563$

Whittaker R.H., 1977, Evolution of species diversity in land communities, [in:] M.K. Hecht., W.C. Steere, B. Wallace (eds), Evolutionary Biology, Plenum, New York. doi: 10.1007/978-1-4615-6953-4_1 